\title{
Foreword to the paperback edition: 'Recovery' 2015
}

John McArthur knows a good deal about recession in post-industrial Britain, and he has recently been learning something about the nature of the current jobs recovery too. ${ }^{1}$

A 59-year-old electronics specialist with a rich $\mathrm{CV}$, he previously worked factory floors, trained and retrained, moved into product development, and even started his own company. But like many others in his part of Lanarkshire, in the central lowlands of Scotland, he has also endured extended spells without work. During the depths of the Great Recession, he put himself forward, through a governmentbacked scheme, to work for LAMH Recycle Ltd in Motherwell, a social enterprise that reconditions computers and other materials. 'It was minimum-wage work, but I was more than happy to do it', he tells me in gentle, intelligent tones. 'I had experience to share. They'd be rekitting televisions and things that would otherwise be getting thrown out, and I'd sit at the end of line, doing the final quality check, signing things off as good to go.'

He was well prepared for the fact that this work would abruptly come to an end at some point, as it duly did in 2011 - 'I always knew the placement would stop, because it had this government backing, and these things do run out.' Nothing, however, could prepare him for what happened next. 
The Future Jobs Fund, which had supported the original placement, was axed soon after David Cameron's arrival in Downing Street in 2010, but in fits and starts his coalition government came forward with make-work schemes of its own. And it was through one of these, 'community work placements', that John was informed in August 2014 there was once again a post for him at LAMH. The new 'offer', however, came with one significant twist: John would be going back to his old job without a wage. He was now being ordered, on pain of losing his benefits, to put in 30 hours per week while continuing to scrape by on Jobseekers' Allowance. The usual weekly rate in 2014/15 is $£ 72.40$.

For John, as for many others, the message of this recovery has been, 'Yes, you can work, but it might not be work as you used to understand it.' For some, what's gone is the presumption of a single workplace with a stable body of colleagues, and all the social connections that come with that. For others, such as the growing army of zerohours workers, what's vanished is the idea of a fixed working week. And for very many others again, another traditional notion has been upended - the old expectation that pay would never actually fall, and would instead tend to creep up over time. As 2014 drew to a close, Britain's economists disagreed about whether or not earnings growth, when properly measured, had truly caught back up with inflation at long last. But all agreed that real-terms pay had been steadily sinking for six straight years. That made for the sharpest pay squeeze since the 1860s, and the most sustained decline on record. ${ }^{2}$

John's invitation to toil for nothing at all might thus be seen as a case of the adverse trends affecting the wider workforce being pushed to a logical extreme. But the case is emblematic, too, of something else that Hard Times talks about - of welfare provisions that had originally been put in place to help people through an hour of need being refashioned into an instrument of punishment. To those on the sharp end, at least, it increasingly feels like strictures that purport to encourage people to pick themselves up are instead operating to keep claimants in their place. 
There was, John says, 'stony silence' when he asked what he was meant to gain in experience from going back to a job he had already done. 'It was being done as punishment, and I felt like dirt. I just think it morally reprehensible that a person is expected to work for no wage, it is as simple as that.' So he wrote to his prospective wage-free employer, LAMH, explaining to them why he felt he had to decline. He received no reply; instead, he found his benefits duly 'sanctioned' for a full six months.

A miniscule pension from a previous job is now all that he has to keep body and soul together, and - as of Christmas 2014 - he describes himself as getting by with 'potato scones - special offer 8 for $6,49 p$ at Lidl - which does me for breakfast and lunch'. And for dinner? '16p tins of spaghetti hoops from Aldi, which I usually have every night.' The diet is 'monotonous', but he doesn't complain, observing that things must be unimaginably worse for sanctioned families raising children.

Perhaps the most poignant feature of John's story - with all the humiliation, as well as the hardship - is that it is playing out during what really ought to be the return of happier economic times. This recovery may have been the slowest to get going in a century, but by summer 2014 it was without question real, and the GDP figures confirmed that the UK economy was bigger than it had been before 2008. Hard Times emphasised that employment had fallen far less than many had feared during the crisis, and, as the recovery beds in, the jobs numbers are continuing to surprise on the upside. In autumn 2014, the employment rate was only a fraction of a percentage point below the pre-crash record.

But all this good news misses the point. For the central argument in the book is that the deep societal problems laid bare by the recession - problems of anxiety and isolation - were always more structural than cyclical. A rich country should be perfectly able to endure getting a bit poorer during a passing downturn. The UK did not run into all the dislocation that we uncover because the crisis suddenly created frailty in downtrodden communities. The role of the slump was rather to expose problems with deep roots in the long decades that came before, decades in which inequality had run out of control. The return 
of growth was never, on its own, going to undo all the damage - and especially not under a version of austerity that passes on so much of the bill run up by the bankers to the poor.

Hard Times draws on almost as much American as British data, highlighting how ordinary workers in the US have been denied any share in a growing economy for a generation or more - for 25 years when family finances are considered in the round, and for 40-plus years where individual male workers are singled out from their wives. The question underlying these transatlantic comparisons was whether the UK is switching to a new American-style normal, in which there is no longer any automatic connection between an expanding economic pie on the one hand, and, on the other, a growing slice for regular employees. The final verdict is still not in, but another year into the recovery, such a suggestion is increasingly hard to dismiss.

In explaining the worrying trends in pay and security, Hard Times points to the substitution of cheap, deunionised labour for costly capital investment. It stresses, too, the disappearance of middling clerking and technical jobs, in a labour market where all the new openings seem to lie in providing care for the elderly, and servicing the wellto-do in restaurants and hotels. All of this stands up well in the unfolding recovery, but, a year on, the connection between low pay and the assault on social security is becoming clearer.

This is true in the latest academic studies, which increasingly register the potential importance of welfare reforms in explaining stagnant pay. $^{3}$ But it is true at the level of common sense and anecdote too. Minimal welfare with maximum stigma is, after all, as Chapter 8 explains, a mix that has long been familiar in low-pay America. The more that stories like John McArthur's come to light - stories of hardship and harsh rules pressing penniless people into taking inappropriate work - the less surprised we should be if employers are holding back on pay rises for their existing staff. What John calls 'an army of conscripts from the Department for Work and Pensions' are providing a ready cut-price alternative.

In this emerging link between squeezed pay for the majority and reduced benefits for the vulnerable few, there really ought to be an 
opening for solidarity, progressive resistance and then progressive reform. Hard Times, however, points to the deep difficulties in the way of building the sort of electoral coalition that might finally turn the tide on inequality. For one thing, we report in Chapter 9 that very many of those who are in work deeply resent those who are without it, a resentment wholeheartedly encouraged by certain politicians and newspaper editors. For another, we uncovered jealousies flowing in every direction in and amongst the dispossessed, with people on one sort of benefit often disdaining those on another.

Can such divisions be overcome? It all depends on which of the two divides discussed in Hard Times emerges as more salient. The first big split is that between the safe (if squeezed) majority, and the large minority that is most insecure, and often dependent on benefits. The second and more politically promising split is the chasm that separates the rich, whose pay and assets have raced away from everybody else for a third of a century, from the rest. And 'the rest' here is an overwhelming majority - Hard Times shows that the squeeze on pay goes at least nine-tenths of the way up the scale. That includes graduates who are settling for the sort of second-best future that all the study and the student debt was meant to save them from. It includes, too, families who have always worked and often done OK, but who now, in this recovery, are raising children in rented homes, where they would once have expected to buy, and generally feeling that life is proving more of a stretch for them than it ever was for their parents. During the last year both these divisions have, in different ways, hardened in the recovering economy. So which is now looking like emerging as the defining divide?

\section{The poor: always with us, at least in this recovery}

The immediate effect of the Great Recession on family incomes was, Hard Times reports, not in fact disproportionately felt by the poor: state action, through taxes and benefits, ensured that the initial squeeze was shared far and wide. But the book also points out that both unemployment proper, and the newer, more distinctive 
blights on working life in this recession - underemployment and zero-hours contracts, for instance - were heavily concentrated at the bottom end. And it warned, too, that the post-crisis assault on welfare benefits could yet push more of the pain onto the most vulnerable.

A year on, these judgements seem, if anything, too nuanced. Important new work from the Institute for Fiscal Studies has unpicked the standard crude assumption that a single inflation rate affects the whole population equally, and instead examined separately the cost of living for different sorts of families. ${ }^{4}$ During the years since the crisis, a number of things that weigh especially heavily in the budgets of poorer families, such as the cost of heating, have risen in price particularly

Being poor got more expensive: average annual effective inflation by income bracket, 2008/09-2013/14

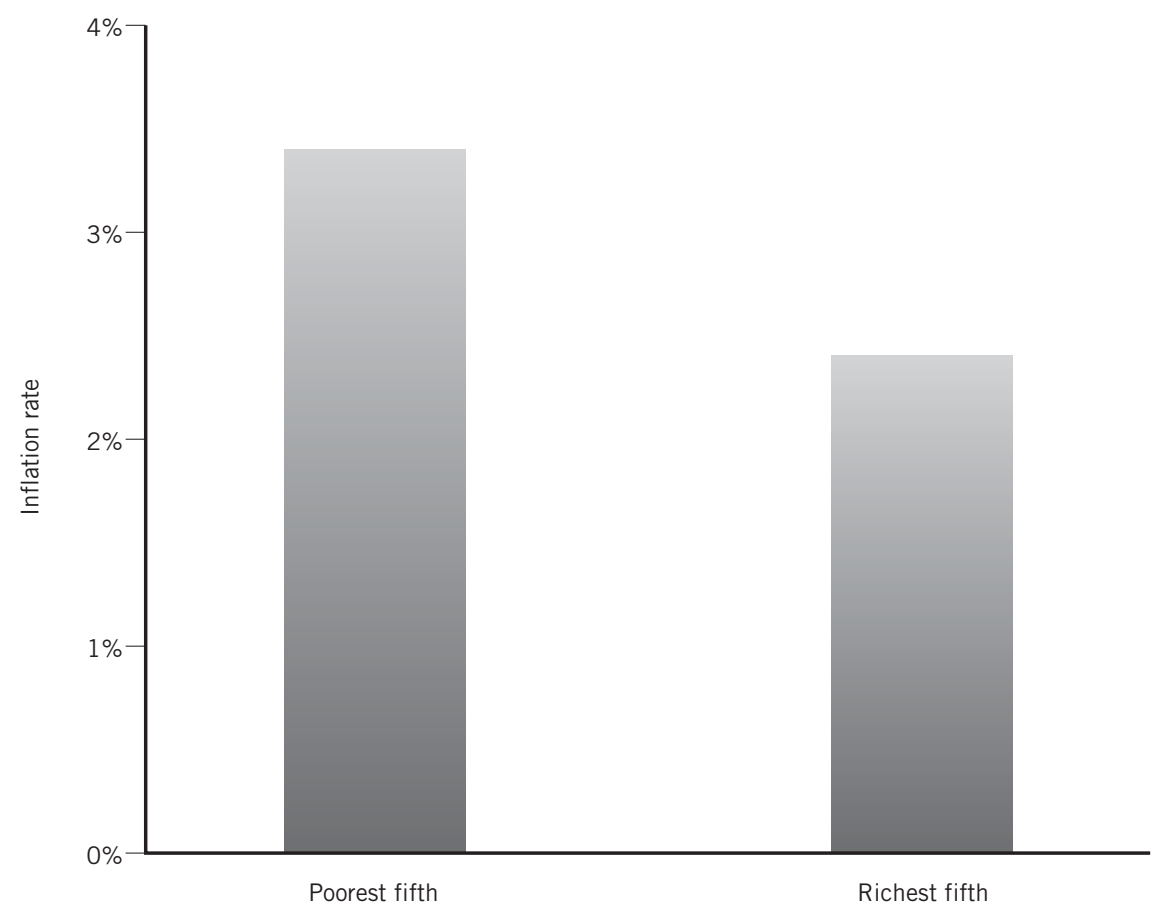

Source: Institute for Fiscal Studies. 
rapidly, whereas that greatest of middle-class costs, mortgage interest payments, has fallen through the floor. Put it all together, and as the chart on the previous page shows, inflation has been running at between one-third and one-half higher for the poor than for the rich. Factor in this differential, and the apparent decline in income inequality that registered in the immediate aftermath of the crisis largely disappears. ${ }^{5}$ As for the subsequent years of austerity, with these true costs of living factored in, the rise in absolute poverty is that bit sharper. ${ }^{6}$

Looking further ahead, the last year has borne out our claim that penury could intensify into the recovery. The University of Essex and the London School of Economics have just produced the first independent study to analyse the UK Coalition's tax and benefit policies, in isolation from those it inherited from the last Labour government. ${ }^{7}$ This has confirmed that the Cameron government has taken most from the income of poorer groups, at the same time as it has advantaged most of those in the top half - including within the very top $1 \%$. As our book argues, too, the pattern of gains and losses has more to do with political choice than economic necessity: the LSE/Essex study concludes that the mix of reductions in direct tax and cuts to welfare payments have yielded no overall gain for the Exchequer.

With unregulated rents continuing to rise, and low wages unaddressed, the underlying pressures for spending on housing benefit and tax credit top-ups for pay packets remain in place. Indeed, the latest official analysis implies that the government will fall short on the welfare savings it promised to secure as a consequence of these pressures. ${ }^{8}$ But instead of searching for new strategies to reduce the demand for state support, the year 2014 saw the Conservative Party resolve to redouble its strategy of reducing benefit entitlements.

In his Budget, Chancellor George Osborne capped non-pension social security expenditure, stipulating that it would no longer be allowed to rise faster than price inflation. Put like that, it sounds reasonable, but over the decades what this assumes is that, however strong the economy, the sick and the workless will never be entitled to any share in rising national prosperity. With rents rising, pay stagnant 
and population increasing, capped expenditure seems almost certain to leave the poor getting poorer.

At the Conservative Party conference, Osborne put in another 'tough guy' turn, proposing to freeze benefits, including for low-paid workers, for two further years at the end of the prolonged squeeze already imposed. Days later, Cameron showered away all the resultant savings (and more) by promising $£ 7$ billion in income tax cuts, some aimed well up the scale. And he promised an even more imbalanced austerity than we have had so far. Where the Conservative John Major had repaired battered public finances after the 1990s recession with a rough 50:50 mix of taxes and spending cuts, the Coalition has relied on a ratio of roughly nine parts cuts to (largely social) expenditure, to only one part tax. In his next term, Cameron said, 'I am confident we will find the savings we need through spending cuts alone', implying a fiscal 'mix' of 100:0. That leaves the state's share in the economy being rolled back to 1930s proportions. Those who depend on IT should be very afraid.

On the raw finances, then, there is now less need for some of the careful caveating that marked out our hardback edition. The poor were not after all much better protected than anyone else when the storm first hit, and the government's evolving direction of travel will push ever more of the pain of adjustment their way. Looking beyond income to economic security - the thing Hard Times argues is so important for community and family life - there are, despite the remarkable jobs growth, stubborn problems at the bottom end of the labour market.

'Underemployment', as measured by those part-timers who would prefer to be working full-time, stood at 1.34 million in the November 2014 data release, which is, as one would expect, down on the dark days of two years before, when this group numbered 1.41 million. ${ }^{9}$ But this is a decline of only around $5 \%$, far smaller than a parallel fall in unemployment of nearly $30 \%$. The band of temporary employees who would rather be full-timers is also proving hard to shrink, remaining at just under 600,000 , compared with something more like 350,000 before the slump hit. As for zero-hours working, the ultimate form of commodified labour, the evidence is at least suggestive of 
continuing growth. Official statistics here are still in their infancy, so it is not yet possible to strip out seasonal variation, but the spring 2014 tally of workers employed in this way stands at 622,000 , as against a late 2013 estimate of 583,000. ${ }^{10}$

Since Hard Times was published, the importance of yet another new form of casualisation has come into the spotlight: 'selfemployment'. Between 2008 and 2014, an extraordinary two-thirds of the total growth in jobs came from an apparent freelance boom. In the first flush of the recovery, this boom concealed a withering away of employed posts in much of the country away from London. To the extent that rising self-employment reflects a new spirit of entrepreneurialism it might be welcome, but something very different appears to be happening at the bottom end. Whereas average real wages for employees have fallen by around $8 \%$ since the crisis, official figures put the cumulative decline in median self-employed earnings at $22 \%{ }^{11}$ Civil servants, who are tasked with trying to prevent fake selfemployment being used to reduce National Insurance contributions, speak privately of hotel chambermaids, shepherds and forestry staff being lopped off the payroll and then asked to come straight back as hired guns.

Much like zero-hours workers, unwilling freelancers have no certainty about what they will be paid or when. This is economic insecurity of exactly the type that will warp first into anxiety, and then into arguments within the home - and broken community connections beyond it. Chapter 6 sets out how a precipitous withering of social involvement accompanied the recession, a decline much more marked on the poorest streets. But it also concluded that there were some tentative signs of civic engagement bouncing back with the economy. Alas, the most recent data suggests that the seeming improvement has not been sustained. Between 2012/13 and 2013/14, the latest government figures show that the proportion of citizens engaged each month in formally organised volunteering or even in trading favours with neighbours has slipped back again. This new decline, which looks even sharper when other forms of civic activism are factored in, appears particularly marked in England's struggling North-East. ${ }^{12}$ 
The economy is still a long way from booming, but if it does get the chance to go at full-throttle before some new crisis emerges, then some of the problems that plague low-paid workers should begin to abate. With truly buoyant demand for labour, employers will find themselves competing with each other to hold on to staff, and no longer able to disregard their wishes in relation to terms and conditions. Other difficulties of struggling families (benefits and tax credits being high on the list) appear set to drag on indefinitely, however, unless something changes. To try and ensure that it doesn't, the political right, ably assisted by its media cheerleaders, will continue stoking middle-class resentment against a subsidised underclass. This tactic will only work if the great squeezed middle can be convinced that it is not in it together' with the poor.

\section{Squeezed middle, narrowed futures}

Pay, Hard Times reports, has been reduced way up into the ranks of the comfortable - nine-tenths of the way up the scale. But we argue that this, on its own, will not do all that much to disrupt middle-class security, particularly if this ultimately proves to be a passing squeeze. Nor will it do much to foster a sense of solidarity with the most vulnerable - a sentiment which the middle class always fears could land it with a tax bill.

Things could play out very differently, however, if the middle class came to feel that its own plans for the future were being threatened by the post-recessionary economy. We report in Chapter 7 on various signs that, for younger people at least, aspirations in terms of home ownership and earnings had taken a serious blow. There was, we explained, an enduring wage penalty to be paid for graduating into a recession, and over the last year new evidence has emerged on the extent to which the young, although on paper the best-qualified generation in history, are earning and owning far less than they would have expected. Home ownership rates for twenty-somethings have halved over the last 20 years, younger adults' pay has stagnated at ages where it always used to rise, and this pattern of making 
less progress than generations gone by extends even to university graduates. $^{13}$

Middle-class parents might imagine that inherited property will eventually correct some of this for their offspring, but what if there is now a more fundamental block on getting on and getting ahead? Most of the evidence about social sclerosis in Hard Times concerns inherited disadvantage at the bottom of the heap, particularly in relation to unemployment. But perhaps the single most intriguing finding to emerge over the last year concerns adverse patterns in social mobility with far wider potential ramifications.

Piecing together data from all the main UK tracking surveys, which follow real individuals on their journey through life, the sociologist Erzsébet Bukodi and Oxford and LSE colleagues have counted the number of steps that successive generations of Britons have taken up and down the class ladder (as defined by occupational grade). ${ }^{14}$ The charts record how many young men and women, assessed at age 27, have advanced or fallen back from the place that their own families occupied on the societal spectrum.

The results show, first, that the earliest baby boomers - born in 1946, and turning 27 at the very end of the post-war 'Golden Age', in 1973 - were very lucky indeed. With both managerial and professional positions proliferating at the top, roughly twice as many young men and women were able to move up as were condemned to move down. Subsequent cohorts, maturing in more unequal times, did not have it quite so good. But right through the 1980s and 1990s there continued to be more steps up than steps down. For those who came of age during the Great Recession, however, things are different - and, for young women at least, there has recently been marginally more downward than upward mobility.

In such data we are, perhaps, witnessing where the great casualisation of labour could take society. Yes, 27 is nowadays rather young to reach a final verdict on a cohort's prospects, and it is conceivable that the picture will brighten for the babies of the 1980s as they move into their thirties. But it is surely conceivable, too, that some of the adverse trends that Chapter 4 reports on as afflicting the low-paid are slowly 
Opportunity knocked: downward social mobility is up, and upward social mobility down for successive generations of British:

\section{(a) men}

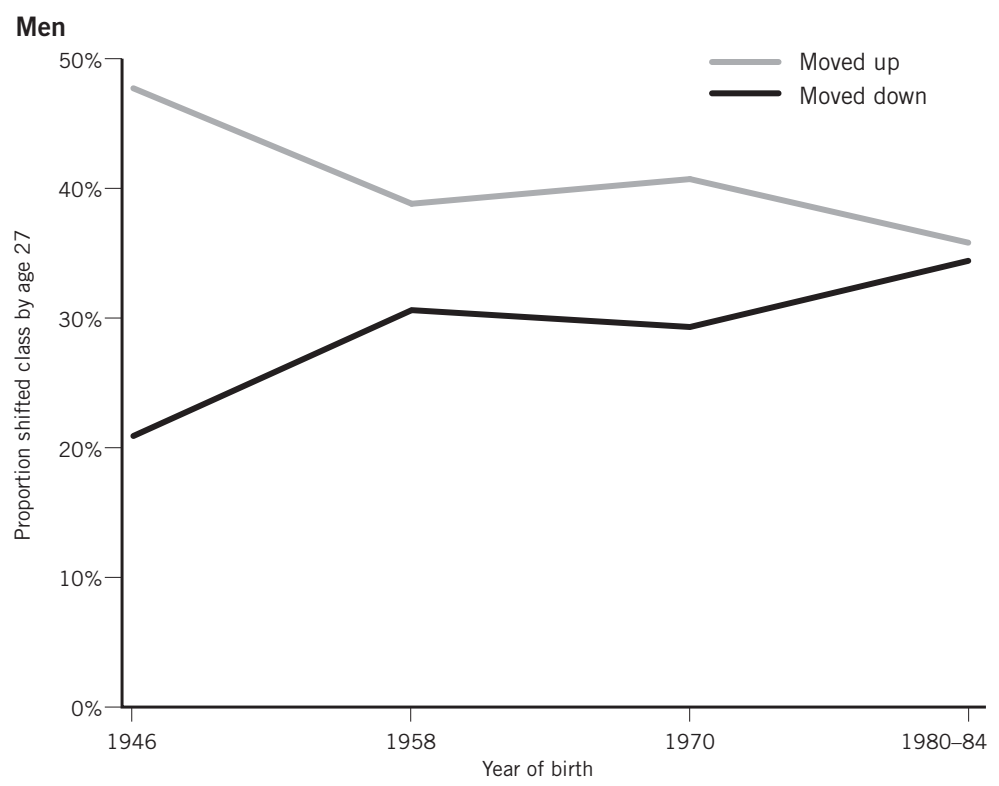

(b) women

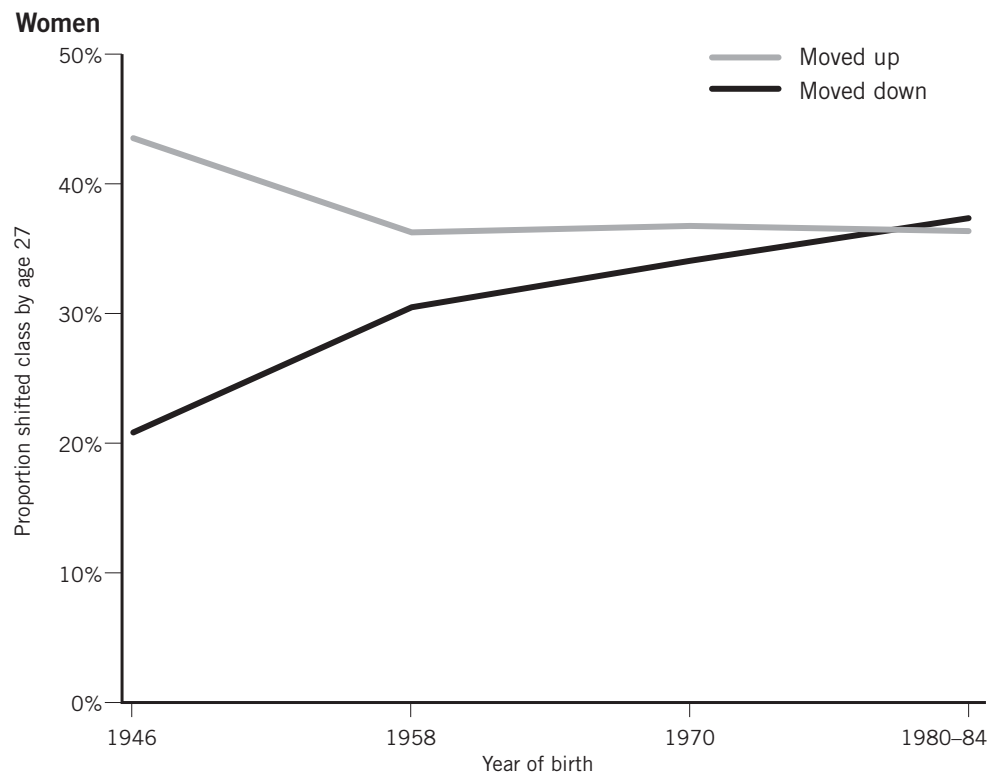

Source: Bukodi et al. (2014). 
making themselves felt farther up the range. Outside of the technology sector and a few elite professions, there is often dwindling room at the top, and dwindling security everywhere else. And of course, the prospects of climbing the ladder in the traditional middle-class way are not helped by the great concentration of wealth at the very top end. Wealthy families can easily stump up for costly Master's degrees and mortgage deposits for their own children - selective advantaging that can often have the effect of diminishing opportunities for everyone else.

It is too early to know what such disturbing sociological patterns will do to political attitudes, although the UK's 2015 general election could provide one early test. The latest updates of the British Social Attitudes data that we analyse in Chapter 9 have been mixed, but are not especially encouraging for the welfare state. The exaggerated perception of mass fraud appears to have eased somewhat, but other varieties of mistrust remain. Excessive benefits are still seen as encouraging idleness, and a seeming swing away from this view in 2012 was not sustained into 2013. Most chillingly, and in line with our argument about political fragmentation among recessionary victims, there has recently been a particular decline in support for unemployment benefits among working respondents who are struggling financially. ${ }^{15}$

But ebbs and flows in support for particular policies and institutions will always come and go. The deeper tide of ideas takes longer to turn, yet is ultimately more powerful. The closing chapter of Hard Times asserts that 'the lop-sided pattern of rewards in the AngloSaxon economies' will 'increase volatility', and with it the dangers of fresh financial crises. It calls for such arguments to 'escape the economics seminar room' and find their way into public debate. The year 2014 has seen this begin to happen. In the spring, Thomas Piketty's Capital in the 21st Century pipped Disney's Frozen: Journey to the Ice Palace to the top spot in the Amazon bestsellers book chart. The huge interest in the French economist's data-rich discourse reflected his emphasis on 'patrimonial capitalism', a system in which great and often inherited wealth will trump any amount of thrift, talent or industry from the middle and lower classes. 
This is certainly not the first sign of a new interest in inequality since the crisis. Just after it broke, in 2009, Richard Wilkinson and Kate Pickett became (surely) the best-selling epidemiologists in history, with The Spirit Level. This sweeping, controversial and contested analysis, subtitled Why more equal societies almost always do better, traced the roots of social ills from crime to obesity back to the income gap. Like Piketty, whose scholarly and little-noticed earlier books feature in our endnotes, Wilkinson had written a good deal before, including in books that had set out the same basic argument with some of the same data. The income inequality numbers may not have changed all that much with the Great Recession, but the mood undeniably did.

Other of this last year's books confirm as much. David Marquand's Mammon's Kingdom bemoaned the warping effect of wealth worship on culture and value in Britain. Sir John Hills' Good Times, Bad Times revives the old argument for the welfare state as something that can help everybody, the middle classes included, through all those financial pinch points that inevitably litter the long road between cradle and grave. On top of these new books comes a previously unimaginable level of interest in inequality at the World Bank, the IMF and on the comment pages of the Financial Times. And, of course, all this interest comes on top of the latest scholarly papers and data that this Foreword has already reviewed.

The best of the analysts and intellectuals emphasise that we are living in interesting times, during which creative options for policy really should be opening up rather than being closed down. Of course, there are real fiscal pressures, but Chancellor Osborne continues to place the deficit ahead of every other objective, promising austerity without end. And yet at the same time the Bank of England is sat on piles of public debt - bonds which it bought with magicked-up money - and shows little sign of wishing to dump onto the market. Even as such a fetish is made of the debt, then, it is becoming possible to see how it could end up being whittled away through quantitative easing, in much the same way that inflation ate into the huge national debts of the past. Official practice is evolving faster than official policy here, 
a sure sign that it is time to challenge some of the conventional macroeconomic wisdom.

New ideas for the labour market are likewise overdue. The unanticipated strength of the bounce-back in jobs holds out the prospect that unemployment could fall to rates not seen since the post-war golden age. Neither inflation nor 'pricing workers out of jobs' are the clear and present dangers that they once were. This invites a less inhibited discussion about regulating labour standards than we have had for a very long time.

Such heretical conversations may not yet be found within the walls of Her Majesty's Treasury. But in the academy, big questions are being asked afresh, and most especially about inequality. There was a time, not so long ago, when the issue of who got what was regarded, at best, as rather tangential to economics proper and, at worst, as a dangerous distraction. The Nobel Laureate, Robert Lucas, spoke for the mainstream when he said that 'of the tendencies that are harmful to sound economics, the most seductive, and in my opinion the most poisonous, is to focus on the question of distribution'. ${ }^{16}$ Having started my career analysing the UK inequality numbers in the 1990s, I remember that mood in economics only too well - as does Piketty, who complains of his own discipline's prioritising of 'highly ideological speculation' over evidence and insight. Today, however, Piketty is himself a real Nobel contender.

The irony is that it was in the 1980s and 1990s, the long years when inequality was ignored, that the economic gap truly shot out of control. It took the Great Recession to wake the world up to what had happened. The hocus pocus of the money men had promised to enrich everyone, but after 2008 the public watched as the alchemy unravelled - and then raged at being handed the bill. As we put it in this book, the tide turned abruptly on the old way of doing business and, as it went out, a lot of rot that had been lurking under the surface suddenly came into full view.

After the long years of neglect, re-engaging with the question of 'who gets what' is not easy. Certainly, mainstream party politicians and establishment policy-makers are struggling to come up with 
answers that are equal to the mood. But the task of tackling inequality is every bit as urgent in the sort of recovery that is now taking shape as it was in the depths of the Great Recession. And if, as Keynes wrote, the ideas of 'academic scribblers' are indeed 'more powerful than is commonly understood', then, sooner or later, change is going to come.

Tom Clark London, 2015 